\title{
The Domestication of Financial Objects: Narrativisation, Appropriation and Affectivation*
}

\author{
KAREL ČADA and KATEŘINA PTÁČKOVÁ** \\ Faculty of Social Science, Charles University, Prague
}

\begin{abstract}
The article explores the general question of how family members articulate the rational and moral dimensions of the economy and the role in this played by language and family discourse- how families do the economy with words. It examines the resources family members employ family discourse to interpret and justify their economic behaviour, and puts forth the hypothesis that economic terms are re-articulated through everyday practices in the family world and that conversations inoculate expert terms with specific meanings. The article introduces the moral economy as a crucial principle of sense-making in family economic discourse and highlights the perception of the future as a key distinction between financial market economies and family-specific moral economies. Three mechanisms by which finance is domesticated are identified: (1) narrativisation-where financial objects are interpreted through the narratives of family history; (2) appropriation-where financial objects are embedded in the family moral economy; and (3) affectivation-where emotions change the meanings attached to financial objects. Narrativisation situates financial objects in time, appropriation sets them in the context of the family-specific moral economy, and affectivation connects them with personal identity and authentic experience.
\end{abstract}

Keywords: family, discourse, economy, financialisation

Sociologický časopis/Czech Sociological Review, 2017, Vol. 53, No. 6: 857-879

https://doi.org/10.13060/00380288.2017.53.6.378

\section{Introduction}

Notwithstanding the turbulent changes in the last century, the family household remains an important part of the contemporary political economy [Gamble 2013]. Even though its importance has been limited in recent decades as a result of most economic production no longer being conducted in the home, a family still plays a crucial role in nurturing and supporting its members through unpaid domestic labour, enabling them to participate in labour markets and supporting those

\footnotetext{
* Acknowledgement: This work was supported by the Czech Science Foundation (grant number 15-04863S).

** Direct all correspondence to: Karel Čada, Faculty of Social Science, Charles University,

U Kř́̌že 8, 15800 Prague 5, Czech Republic, e-mail: kcada1@gmail.com

C Sociologický ústav AV ČR, v.v.i., Praha 2017
} 
who cannot. Furthermore, with respect to economic behaviour, families are also sites of financial socialisation [Churchill and Moschis 1979; Moschis and Churchill 1978], where children and young people acquire the skills, knowledge, and attitudes they need to function in the marketplace.

In our article, we focus on the general question of how family members articulate the rational and moral dimension of economy. In contrast to economic studies of the family [Aaker and Lee 2001; Commuri and Gentry 2005; Cotte and Wood 2004; Hamilton and Biehal 2005; Moore, Wilkie and Lutz 2002; Tian and Belk 2005], which put emphasis on families as economic units, or in contrast to traditional class analyses [see Atkinson 2014], which predominantly question the influence of economic conditions on family life, we study the role of language and discourse: how families do economy with words.

In recent years, various scholars [Holmes 2014; Maesse 2015; Appadurai 2016; McCloskey 2016] have started to look for the discursive dimensions of diverse economic elements. These authors have used discursive lenses to grasp the dynamics of central banks, financial markets, and the birth of capitalism. In contrast to these studies, we do not deal with macro issues and global phenomena. Our article aims to provide an insight into small domestic worlds to demonstrate that discursive perspectives are valuable not only in the studies of macro phenomena, but also in the examination of mundane economic behaviour. We focus on what rhetorical resources family members employ in interpreting and justifying their economic behaviour. How is family discourse related to public economic discourse and how are economic terms translated in domestic talk?

We hypothesise that economic terms are re-articulated through everyday practices in family worlds and conversations that follow their own logic and that inoculate the expert terms with specific meanings. We focus on how financial discourse is translated in family life and how it is domesticised by the family world. Our article introduces the moral economy as a crucial principle of sense-making in family economic discourse and highlights the concept of the future as a key distinction between the rational capitalist economy and the family moral economy. Whereas the capitalist financial system is founded on a promissory discourse of rising future expectations [see Appadurai 2016 or Beckert 2016], the family moral system is related to the cautious discourse of future threats.

In the article, we discuss key modes of domestication of the financial economy: (1) narrativisation; (2) appropriation; and (3) affectivation. We identified these modes based on a literature review; consequently, we use family discussion transcripts to illustrate our theoretical concepts. Our article seeks to explore how families translate the world of the economy into their domestic zone and, in general terms, to understand how public discourse interferes with private lives. 


\section{Family as a discourse}

Economic literature predominantly views the family as a collective enterprise in which (1) multiple parties are engaged; (2) the common good is generated, and (3) collective ownership of assets is denoted. In the 1970s, the new home economy made an analogy between the firm and the family [Schultz 1974: 8]. In contrast to the economic definition of family, our article relies on the definition of family as an interpretative practice [Gubrium and Holstein 1995].

Kandall [2007:3] defines the family as the original site of everyday discourse and a touchstone for talk in other contexts. Families are created in part through talk, including the daily management of a household and the intimate conversation that forges and maintains relationships, and family is the site for the negotiation of values and beliefs. Families are not only units or social institutions, they also represent living, dynamic environments that require considerable coordination to sustain themselves, and language plays a critical role in this endeavour [Ochs and Kremer-Sedlik 2015: 729].

The language in families has both a dialogical and a narrative character. Family talks serve to (1) coordinate daily activities [Klein, Izquierdo and Bradbury 2007], (2) construct a shared family identity [Gordon 2007], and (3) socialise members into family roles [Pontecorvo and Fasulo 1999]. Bratman [1992] identifies three key requirements from the participants: (1) mutual responsiveness, (2) commitment to the joint activity, and (3) commitment to mutual support. This mutual responsiveness and commitment to joint activity and mutual support is expressed through politeness as an essential code of family discourse with three dominant tones of politeness: power, informality, and affect [Blum-Kulka 1990].

Story-telling is a means through which a family discourse is constituted: 'For a family to construct a coherent narrative together, each part of the story must be explained. The members of the family may challenge what was told, add in different pieces, or critique and rework the current "theory" of what happened.' [Bohanek et al. 2006] Fivush [2008] foregrounds that reminiscing is part of everyday social interactions within virtually all families. In families, narratives can be seen as methods of obtaining information, as a medium of socialisation, and as a medium of meaning-making [Pratt and Fiese 2004]. Each family has a repertoire of stories in circulation. They present what happened in the past, what past events mean, and the evaluation or moral significance of these events [Czarniawska 2004: 36].

Jaber Gubrium and James Holstein [1993] see family discourse as both substantive and active. Its substance (stock of knowledge) refers to terminology, images, mental models, and theories. This part represents the conceptual resources for interpreting interpersonal relations. Substantive practices relate to the received knowledge, ideas, and models that underpin practice and policies. The active, or procedural, part of family discourse provides directives for how one intends to look at and understand what is referenced and observed. Active 
practices emanate from these in terms of the day-to-day actions of the individual practitioners and their assessment. Family relations constitute so many smallscale 'fields' in Pierre Bourdieu's sense: relatively autonomous systems of relations between agents who are united in a common mode of recognition and by automatic assumptions about 'what one does', differentiated by unequal possession of power [see Atkinson 2014]. For Bourdieu [1996], what different definitions of family have in common is the fact that they suggest that the family exists as a separate unit. In this sense, family discourse constitutes family practices [Morgan 1996, 2011; Gillies 2003], which may be best thought of as behaviours linked to family living which, in their very existence, demarcate family living from other non-family forms of living or being. The concept of practices refers to the fact that family relationships are not only interpersonal relationships, but simultaneously also cultural conceptions and institutional arrangements.

Family practices are not constructed only by communication and dialogue, but also by material objects and the way they are dealt with. Shalley Day Sclater [2008: 143] shows how material objects, such as a farmhouse, Monopoly, Welsh cakes, wellies, or money, make us feel like a family and construct family holidays as 'family time'. With respect to economic practices, Jan Phillips [2009] speaks about overarching orientations toward goods and services (Bourdieu's 'habitus'), the symbolic value read into goods and services (signs and status), taught knowledge about goods and services (socialisation), or everyday consumption interchanges, the mutually constitutive practices between family members.

Family practices are organisationally embedded and situationally sensitive. They are conditioned by the setting in which they occur. Family practices are delimited by sociohistorical context-collective representations (in the sense of Emile Durkheim)—about 'domestic life' [Gubrium and Holstein 1993: 662]. The organisational embeddedness refers to the circumstances in which domestic order is constituted, not the actual integration of family members into the working life of organisations [Gubrium and Holstein 1993: 68]. With respect to concrete local organisations and their interactions with families, one can speak about local cultures of domesticity. Local culture, organisational settings, and institutional structures 'provide discernible frames of interpretation and standards of accountability to which members orient as they engage in constructive activities' [Holstein and Gubrium 2008: 380].

Nikolas Rose speaks in a similar sense about 'familialising projects' that 'sought to utilise the family and the relationships within it as a kind of social or socialising machine to fulfil various objectives: military, industrial and moral' [Rose 1987: 73]. Familialising projects, through the discourse of law, policy, economy, or science, socialise, shape, and maximise personal capacities and conduct in accordance with the moral and political principles of liberal society. Following this logic, Haney and March [2003], for example, show how welfare discourse has changed the 'appropriate' attributes of fathers and the way a father's role is perceived. 
Figure 1. Embeddedness of family discourse

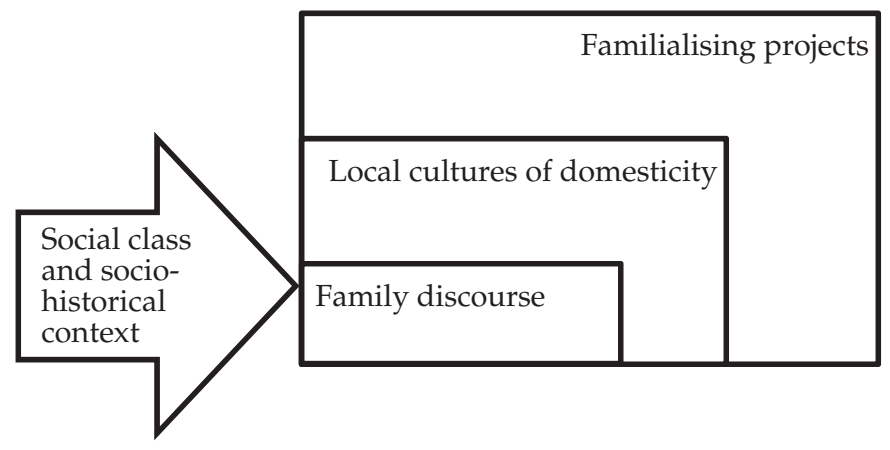

Summing up the discursive approach to family, several points need to be highlighted. Language plays a key role in the construction of the family, particularly by recruiting and coordinating the attention, emotion, and actions of family members. These recruiting and coordinating activities are multi-directionally produced and negotiated.

Family discourse as a practice based upon a narrative mode of recognition, however, has societal and historical dimensions. Using Bourdieu's conceptualisation, the constitutive elements of family economic discourse can be explored as specific doxa [see Atkinson 2014] —a situation where the arbitrary appears natural and where important issues remain taken for granted. It is embedded in local cultures of domesticity and broad familialising projects. Through the local culture domesticity and familialising project, the family exists not only as an organisational unit and practical entity, but also as a generalisable, realised, and moral category.

\section{The logic of the moral economy and the logic of the calculative economy}

Viviana Zelizer proved that domestic money is special money. It is not just a 'medium of economic exchange, but a meaningful, socially constructed currency, shaped by the domestic sphere, where it circulates' [1989: 369-370]. Domestic money thus shows the limits of a purely instrumental, rationalised model of market money, which conceals qualitative distinctions among kinds of money in the modern world. Domestic money is relational money embedded in social ties, economic transactions, and media of exchange. This model moves away from money as homogenous medium in direction to different categories of monies. To focus on general monetary practices, Nigel Dodds suggests that money cannot be seen as a thing that is simply mapped onto social and cultural spaces, but 'rather a process through which various kinds of human association are actively created and valued' [Dodd 2014: 294]. 
Building on Zelizer's frameworks, Supriya Singh [1997] looks at the role of money in marriage. She shows how marriage money reflects the marriage relationship: how the growth of a joint account reflects the sharing and pooling of money, while at the same time masking questions about power and dependence. However, she also pays attention to the intervention of market money in the domestic sphere, and how developments in banking technology have changed the way couples manage their money.

Associating monies with power, moral obligations, or a hierarchy of personal dependencies opens the door for considering family economies as moral economies. Amartya Sen distinguished between 'engineering' and 'ethical' approaches to economics [Sen 1991]. The former was developed from technique-oriented analyses, treating economies as machines that have their own rules. Conversely, the ethical approach treats economies as sets of social relations, including motivation, and of social achievement, which can be assessed in moral terms. ${ }^{1}$ Sen prefigures the main question of our article, which can be re-articulated: what is the relationship between the language of engineering approaches to economics and ethical ones?

James Scott [1976] identified three core principles of moral economies: (1) subsistence ethic, (2) reciprocity, and (3) the 'safety first' principle. To guarantee their existence, Scott's peasants prefer 'to minimize the probability of having disaster rather than maximizing their average return' [Scott 1976: 18]. To understand the household as a moral economy system is to understand how the household, as part of a transactional system dynamically involved in the public world, creates and sustains its autonomy and identity as an economic, social, and cultural unit [Silverstone et al. 1992].

With respect to poor families, Daly and Kelly [2015] describe the crucial conflict between the rational economy and the moral economy. This conflict puts families in paradoxical situations. Cutbacks driven by the rational economy, such as to family holidays and family days out, weaken family practices that are necessary for family togetherness and family building. Families locate their decisions in a complex moral frame where the interests and needs of children outweigh personal considerations. For example, expenditures on children's social activities that might be seen luxurious from the point of view of the rational economy are seen as legitimate because of the order of the moral economy.

This conflict may be interpreted as a conflict between family mental accounting defined by Thaler as 'a set of cognitive operations used by individuals

\footnotetext{
1 Booth [1993] argues that even market economies are moral economies. What distinguishes them is the specific form of the morality in which they are embedded, not their lack of any such morality. On the other hand, they do not share in the morality of 'the community as a whole'; they might instead have 'their own' normative character. Market economies are moral but not ethical, concerned with questions of human good and well-being, whereas non-market economies (such as households) might be both moral and ethical.
} 
and household to organize, evaluate and keep track on financial activities' [Thaler 1999: 183] and the moral economy of relational earmarking that moves beyond the individual cognitive process by focusing on relational work [Zelizer 2012]. Whereas the first one is based upon mundane rational cost-benefit analysis, the other-the relational moral economy-demarcates what is respectable and acceptable. Both principles are based on the non-fungibility of domestic moneythe value of money varies in different situations [Morduch 2017]. In family mental accounting, departing from fungibility is founded on the existence of separate accounts for different needs-what is called the 'tin can economy' [Zelizer 1994]. The nonfungibility of money in relational earmarking is marked by bargaining between different family members with different control over money, moral norms, and emotional work. Relational work, which may be intentional or habitual, places social relationships at the centre of the family economy [Bandelj 2012]. As Wherry [2017], who echoes Jeffrey Alexander's [2006] perspective, argues the relational accounting relies both on the individual interacting of family members and on trans-situational cultural codes for moral evaluation. Cultural codes that function in hierarchies [Battigalli, Siniscalchi 1999] define morally preferable actions and close off some courses of action as unthinkable. Cultural codes work in binary oppositions and they supply the structured categories of pure and impure into which every member, or potential member, of society fits.

The complementarity of rational and relational accounting practices questions Bourdieu's assumption [Bourdieu 1996] that a family is a world in which the ordinary laws of economy are suspended in favour of affection and solidarity. Overlooking cost-benefit mental accounting in family economies represents the same type of mistake as mainstream economists' ignorance of relational work and moral practice.

Relational moral economy contrasts with the larger portion of the current calculative financial economy works by making profit on the monetarisation of risk, and risk is available to the financial markets through debt. Appadurai [2016] and Beckert [2016] highlight the promissory aspect of the financial economy. The promissory aspect of financial capitalism is driven by the idea of risk and investment. For Becker, investment decisions are anchored in fictional expectations. Investments are motivated by an imaginary future supported by calculations that can overcome the limit of our intuition. They are unique and directed to an open future. Investment calculation demands foresight and imagination, including opportunity-seeking and information-gathering [Orleán 2014: 114].

With respect to investments, Sayer [2015] distinguished between objectfocused definitions and investor-focused definitions. The former focuses on the usefulness and benefit in the future, the latter focuses on financial gains to the investor. The financial sector uses the term mainly in the second sense. On the other hand, the object-focused definition of investment may play an important role in the realm of moral economy.

The relationship between moral economy of family and calculative financial capitalism corresponds with Max Weber's [1978: 379-384] distinction between 
a household and an enterprise. Whereas householding is an economic action aimed at satisfying needs, enterprise is oriented towards profit-making. The first can be associated with categories of wealth and income, the latter with categories of capital and profit. Both householding and profit-making may be traditional as well as rational. Unlike traditional households, Weber argues, a modern household has elements of rational action, such as budgeting or accounting. Nevertheless, it still differs from an enterprise in its orientation.

However, it would be a mistake to see the moral economy and calculative capitalism as two separate entities. Over the past decades, scholars from different disciplines have used the concept of financialisation as a way of underscoring the growing power of financial markets and financial institutions in political and social life [see Engelen 2008; Krippner 2012]. With respect to this shift, for instance, Martin [2002] speaks about the financialisation of daily life and Aalbers [2008] about the financialisation of the home. Aalberts notes: 'The rules and logic of Wall Street are increasingly becoming the rules and logic outside Wall Street.' [2008: 149] In the same context, Appadurai [2016] describes housing mortgages and derivatives as the key to the financial rematerialisation of the American home. The financialisation literature examines how innovation in banking integrates individuals or households into capital markets through transformations in households' investments and borrowing patterns [Montgomerie 2006].

Through the processes of financialisation, economic logic penetrated everyday realms that had previously been considered free from economic calculations [see Pellandini-Simányi et al. 2015]. Furthermore, according to the financialisation literature, the logic of an engineering economy seems to have won out over the logic of an ethical economy. This type of critique recalls Jürgen Habermas's [1987] concepts of conflict between the system and the lifeworld. For Habermas, the system means structures and patterns of instrumental rationality and action, particularly money and power, whose main function is the production of goods and services. Conversely, the lifeworld, identified with the household, means shared meaning and understanding. Due to the impact of capitalism, the lifeworld has been colonised, eroded, and impoverished by the system. The same argument was adopted by Hochschild [2003] in speaking about the penetration of the intimate life by the forces of commercialisation and commodification.

In relation to this shift, existing studies predominantly examine the discourse of financial institutions as a familialising project transforming lay people into reasonable economic actors. However, lay people's experience was largely ignored. As Pellandini-Simányi et al. note the financialisation literature has generated a sophisticated description of the institutional causes of the financialisation of everyday life, with 'hardly any insight into whether and how this financialization is actually taking place' [2015: 735].

Parts of the article above have shown that families are resistant to the discourse of financial capitalism. They have moreover adopted the terms used in financial discourse, and translated and domesticated them. Pellandini-Simányi 
et al. [2015] describe the domestication of the financial process as follows: 'the financial object reorganizes certain relations of the domestic world, but it becomes entangled in that world' [737]. For Pellandini-Simányi et al., domestication means fitting the financial-rational into already existing calculations and everyday rationalities; it is about how financial logic is socially embedded [Granovetter 1985] in family practice and family discourse. The concept of domestication puts emphasis on the active role of the domestic world in adopting financial instruments into everyday life. The financial instruments are not enacted unchanged; however, they are actively translated into family discourse and become entangled in the different logic of family economies.

To shed light on the translation of financial objects into the family economy, this article examines the following discursive practices:

(1) Saving and spending: How do families talk about saving and spending money? What is the preferred economic behaviour of a family?

(2) Debts and loans: How do families talk about debts and loans? How do families deal with unexpected situations?

(3) Financial institutions: How do families talk about financial institutions such as banks, funds, banking advisors, etc.?

(4) Financial objects: How do families talk about loans, mortgages, investment funds, savings accounts, insurance, etc.? How do families use economic terms?

\section{Data and methods}

The corpus of family discourse we analysed consists of family discussions on savings, spending, and frugality. The discussions were organised and run by undergraduate students in sociology at Charles University within their own families and included three generations - the students themselves, their parents, and their grandparents. The three generations do not live together and the discussions took place as part of family get-togethers.

To induce spontaneous talk between family members, the discussions were elicited with a set of questions on saving and spending money. Our analysis focuses particularly on these moments of spontaneous talk. The conversations have been recorded and transcribed.

We have analysed transcripts from 15 family discussions. Since the students are from all around the country and from different social strata, the sample covers the main socio-geographic areas of the Czech Republic. The clear majority of the interviewees are from middle-class families. ${ }^{2}$

\footnotetext{
${ }^{2}$ We define middle-class families, in the Weberian sense, as the broad category of families who fall socio-economically between the working class and the upper class.
} 
In the analysis, we identify the dominant moral code of family discourse. In line with Lamont and Thévenot [2000: 6], we focus specifically: (1) on 'the content of criteria or orders of justification used to draw boundaries between the more and the less valuable'; (2) on 'whether and how different criteria compete with one another and are used in conjunction with one another'; (3) on 'how actors demonstrate the situational appropriateness of their criteria of evaluation' and on "investments of forms" processes by which people and things are defined as belonging to similar classes across contexts'.

As well as moral codes, we focus on the categories that families associate with economic terms in their family talk-investments, mortgages, loans. We study contexts in which these terms are used and the meanings ascribed to them by the respondents.

\section{The moral codes of the family economy}

The economic discourse of families emphasises ways of reducing sources of uncertainty and preventing possible harmful events, even inherently unknown ones, from befalling families. People seek to have a buffer against such general uncertainty, 'if something were to happen'. They highlight the need to be prepared for possible 'difficult times' or 'family troubles'. Their awareness is associated with the version of the future they anticipate. In contrast to the promissory logic of financial capitalism, they express more scepticism and hesitancy about the future: 'I always believe it could be worse. I would never live, like others, hand to mouth. I'm always saving some crowns, as you never know what might happen.' (a man in the parental generation). The financial autonomy guarantees security and stability for our respondents. Financial autonomy is associated with the sustainability of family finance: 'You have to spend less than you earn.' (a woman in the parental generation) The balance between spending and earning is a moral imperative, one that was shared by the majority of our respondents. ${ }^{3}$

Financial autonomy does not mean only financial sustainability, but also control over money. This principle is illustrated by the Czech idiom: 'It's what's at home that counts.' This control over money has different elements: (1) managerial elements-guaranteed access to money when one needs it; (2) emotional elements-trusting people who operate with money; and (3) cognitive elementsunderstanding of how money flows. Our data indicate that decisions about financial products very often rest on these three principles. Financial stability and permanence are contrasted with the uncertain and changing external world, which is symbolised by banks, associated with speculation and instability.

\footnotetext{
3 According to public opinion polls [CVVM 2010], the clear majority of Czechs is aware of the importance of creating financial reserves. Compared to the declared intention, only two-thirds of the Czech population claimed to have such a financial buffer.
} 
The need for financial autonomy is less associated with existential survival, but rather more with self-respect and dignity. The need for a financial buffer, legitimised by autonomy and self-sufficiency, defines a family as a social unit and the boundaries of such a unit. The financial autonomy and financial buffer represent a moral obligation on which all generations agree. This moral obligation also leads to the condemnation of people who live day by day, with no financial security, for being dependent, irrational, and wild-passionate and for lacking self-control.

Responsibility and self-control are usually demonstrated by avoiding debt and saving money. Debts and savings are the crucial categories in the order of the family economy. Financial autonomy and savings as a source of respect and dignity are actively accounted for in everyday conversations and underscored by an extreme formulation ('I've always saved something') constructed as a biographical virtue ('I've saved money since childhood') and appraised in family discourse ('So, the fact that you were able to save some money from your earnings-hats off! I admire my parents for saving small amounts' - a man in the student generation). On the other hand, debts are risky and dangerous: 'When we need to borrow money, we do so, but only within our family.' (a woman in the parental generation) In this case, the family discourse also favours trusting and friendly relations over the anonymous relations of the market.

However, there are some justified exceptions-for example, when a person needs money to support relatives, when a person buys a house / flat, or when a person is in an unpredictable situation (very often illness), since these are situations that can negatively influence a family's stability and security. On the other hand, debt is morally condemned when it is the result of avoidable consumption wants or when it leads to extensive spending. In this view, the family moral economy worships rational, reasonable, realistic individuals who exercise self-control over individuals driven by passions.

Even though there are differences between the generations in how they plan to save, they almost unanimously agree on the obligation to save. The student generation usually refers to saving in order to buy something, and for them saving is much more often associated with consumption. Nevertheless, this type of saving for something is described as an important part of financial socialisation and as a way to practice financially responsible behaviour. By this logic, the strength of saving as a category can legitimise spending, if you have saved the money beforehand. Saving makes spending a self-controlled act. The parental and grandparental generation predominantly refer to saving in order to ensure autonomy - if something were to happen - and saving for the future generation. They also refer to their saving as a moral obligation - to put something away for a rainy day'.

Domestic money defines different discursive zones of autonomy and responsibility. Claiming these zones relies on the biographical situation of family members, changes during the lifespan of the family, and different rites of passages 
Table 1. The binary structure of the family moral economy

\begin{tabular}{ll}
\hline Moral & Immoral \\
\hline Autonomy & Dependency \\
Stability & Instability \\
Responsibility & Irresponsibility \\
Security & Risk \\
Financial Buffer & Debt \\
Saving & Spending \\
\hline
\end{tabular}

(such as marriage, leaving the parents' home, etc.). Different conceptions of individual members' autonomy and responsibility of the individual members reside under the umbrella of the autonomy and responsibility of the family as a whole.

In the family interviews, the grandparent generation stressed their independence from their children, because they had saved money for their care-givers or their funerals. The child generation stressed their independence from their parents' money. On the other hand, family members will give up their financial autonomy in favour of the autonomy of the family as a whole. This is reflected in the sharing of money or members delegating their financial responsibilities to someone else.

Being prepared can be identified as the core of the discourse of the moral economy of families. Having a financial buffer is considered a duty and saving is considered a matter of self-discipline. This argument strongly resembles the safety-first economics of subsistence described by James Scott [1976] in his account of economic strategies of farmers living close to the edge of subsistence. In contrast to James Scott's poor peasant families, our respondents belong to the Czech middle class and can rely on the safety net of the welfare state if something unexpected were to happen.

With respect to justified motives and relations, the symbolic structure of the family moral economy resembles Jeffrey Alexander's code of civil society [2006], with its stress on active, autonomous, rational, reasonable, calm, self-controlled, realistic, and sane motives and on the open, trusting, critical, honourable, altruistic, truthful, straightforward, friendly, and deliberative dimensions. The binary code of the moral economy of middle-class families replicates the liberal code of civil society in relation to motives and relationships. From this perspective, family discourse cannot be inherently different from the code of civil society, and rather as an integral part of the modern moral code follows, at least at discursive levels, the same principles and binary categories.

Apart from the symbolic codes defining the preferred motives of individuals and the nature of relations, there is a set of binary codes that define the family 
moral economy as an institution. Given the discursive structure of motives and relationships, these two sets of homologies and antipathies extend the structure of social understanding of the moral family economy itself. This structure is presented in Table 1.

\section{The materialisation of the family economy's moral codes}

Moral obligations are constantly recalling in family discourses through different material representations. One respondent, for example, used a photo, presented by a student, as the best representation of her relation to money:

I have a picture, where there is a flower growing out of money in a hand. I like it because I think the same. Money makes money. When you save money and keep money, you grow. You can buy what you want. But, more importantly, you have a buffer. So, it doesn't happen that someone wants money and you don't have any. (a woman in the parental generation)

For another respondent, old furniture constituted the materialisation of the moral order:

We still have old furniture. When I went to my brother's home, they had new furniture. We fell in love with oak, they said to me. The old furniture had been thrown away. And they have no money. (a man in the parental generation)

The home as the site of family discourse is a places where the family moral economy is being recalled, accounted, and created day by day. Credit cards and electronic bank-account statements are for the older generation evidence of the lack of self-control among the younger generation. Credit cards are mainly associated with paying, not with borrowing. ${ }^{4}$

Different objects are mobilised to register someone's overspending or frugality. Objects are also an essential part of a family's tin-can economy, where different boxes mark out the different uses of money and keep different monies separate. In this context, housing represents the most important materialisation of the family moral economy combining calculative and relational elements, and symbolizing a core code of autonomy and responsibility.

Investing in real estate is rational, because renting a flat is like throwing money away, instead of paying for your own place. One builds something and

\footnotetext{
${ }^{4}$ Rona-Tas and Guseva [2014: 116] note that, unlike in the United States, where the card market began with credit cards, in Central European countries, including the Czech Republic, debit cards arrived first and American-style credit cards are still few.
} 
then is proud of it, and it can help one's children. (a man in the parental generation)

In the moral economy of the family, housing is a collective representation that provides both the deep background for social performance and the foreground, the scripts that are the immediate referent for action [Alexander 2004]. Housing is a symbol of the moral code of the family's economy; housing constructs the performative imagination of the family and is crucial to the performance of the family's moral economy. Housing is an investment in the entire family. It is the commodity that is the materialisation of family values and family in general. In this sense, our respondents distinguish housing from individual consumption. Finally, when people invest in their own housing, it means they do not need to pay rent to someone else. The money will stay in the family.

\section{Three forms of domestication of financial products: narrativisation, appropriation and affectivation}

Domestic talk on economy differs in many aspects from the discourse of financial institutions. The moral family economy lacks promissory aspects, combines calculative elements with relational ones, and is based upon the non-fungibility of domestic money. The rational economy of financial capitalism is focused on individual profit, while the dominant goal for the moral economy is the survival of the family. While the discourse of the financial economy is dominated by the concept of opportunities, the moral family economy, based upon risk-aversion, associates the future with uncertainty and sees it predominantly as a source of threat.

Family discourse is not separate from the discourse of the financial economy. Families are influenced by the discourse of financial institutions. Families translate financial discourse and the financial object into the vocabulary and grammar of the family moral economy - they domesticate them. In our data, we identified three mechanisms of the domestication of finance: (1) narration-when financial objects are interpreted through narratives of family history; (2) appropriationwhen financial objects are embedded in the family-specific moral economy; and (3) affection-when the meanings of financial objects are changed through emotions.

\section{Narrativisation}

Family memories and histories serve as methods of constant dialogue between the past, present, and future through the reflection of past expectations to articulate recent expectations. As Brown and Michael [2003] remind us, people not only use memories by redeploying them to manage or engage with the future, but they also refer to the way the future was once represented, as distinct from the way it is currently represented. 
For us, family memories and family histories seem to be key modes for the interpreting of financial objects. The last three Czech generations, for example, have very different experiences with different economic systems that have different logics. While the student generation was born after the fall of the communist regime, the students' grandparents lived most of their lives through the communist period (1948-1989). At that time, the centralised economic structure markedly differed from market or mixed economies. Everyday life was punctuated by frequent periodic shortages of consumer goods, thriving black markets, and the important role of self-supply in many areas. The functioning of the economic system was determined by massive general distrust in political and administrative institutions. Many of the respondents in the oldest generation also remember the currency reform in 1953, when a surprise drastic devaluation of the Czechoslovak Crown by a factor of 50:1 was announced. This had significant consequences for the family economies, in both the immediate and the long term. Most of the parent generation was also born and raised during communism, while their adulthood was spent in the nascent democratic capitalist regime. The collapse of communism produced an extraordinary euphoria and raised huge expectations. Obviously, not all of them were fulfilled. This period was marked by massive privatisation, an unprecedented boom in financial institutions such as banks and investment funds in the early 1990s, the bankruptcies of them at the end of the 1990s, and stories about the asset-stripping of banks and, funds or privatised firms being transferred out for the benefit of those who controlled them. ${ }^{5}$

With respect to family history, financial objects—such as investments, mortgages, or funds-represent the markers of specific periods (in life) and evidence of an unstable and changeable world. Putting them into family narratives underlines their temporal character.

I told Zdena [a daughter] our family history about how we lost the money we saved owing to the currency reform and how the reform influenced our behaviour. We had saved money for our own house and the money totally lost its value. My grandma and grandpa lived in horrible conditions-in a bad flat with the toilets outside. They regularly walked to see the house they had been planning to buy. In the family, there was lots of talk about uncertainty when you deposit your money in the bank. It is part of our family story. (a woman in the parental generation)

Entities that financial discourse considers to be taken for granted are questioned, problematised, and partly deconstructed by family narratives. Family stories serve as a reminder of their temporal character. To domesticate financial objects through narratives means giving them a temporal dimension and putting them

\footnotetext{
5 There is a strong opinion that the deregulation of prices after 1989 and the process of coupon privatisation were unfair steps. More than half (54\%) of Czechs think the privatisation process was unfair and only a quarter (26\%) feel it was fair [CVVM 2009].
} 
in a historical context. Narrativisation entails reflecting on past expectations, where previous expectations are confronted with their consequences and serve as the basis for drawing conclusions about present events and possible futures. Family narratives also establish and replicate binary codes and re-establish what is morally right or morally wrong.

\section{Appropriation}

Whereas narrativisation means situating financial objects in familial time, appropriation means situating financial objects in the moral code of the family economy. Appropriation is a mechanism whereby something that, according to the dominant moral codes, is not the preferable action, can be justified as preferable, and whereby it is possible to cross the boundaries of binary codes in the family moral economy. We identify two different modes of appropriation: (1) putting financial objects into hierarchical order and (2) using financial objects as metaphors.

Moral beliefs about right and wrong operate in a hierarchy and these beliefs are matched to different types of relationship. The best examples of such appropriation are mortgages. The meaning of a mortgage is not calculated, the way economists see it, but is derived from housing as a collective representation of the moral economy of the family.

It seems that financial institutions do not colonise family life with their impact on rationalisation and calculation; on the contrary, the moral evaluation of family life, with its emphasis on autonomy and stability, makes a mortgage valuable. Through housing as a dominant representation of the family's moral economy, the family interprets financial products such as loans and mortgages in economic terms as investments. The financial object is appropriated to the logic of the family-specific moral economy. When it comes to obtaining housing, a person can spend a large sum of money, borrow money from a bank, or use their financial buffer, because as a representation of the code of the moral economy housing is associated with stability, security, and intergenerational transfer. ${ }^{6}$

Even though a mortgage is a loan, which in the dominant (moral) order is a morally problematic category, the meaning of housing changes symbolic moral boundaries are transgressed so that a mortgage is the converted into a justified and preferable category. Unlike debts, which are considered irresponsible, a mortgage has positive connotations. It is proof that a person is dealing responsibly with their housing situation and guarantees that they are not spending too much money: 'How many flats would they now have if they'd gotten a mortgage?

\footnotetext{
6 Public opinion polls confirm this outlook. For the Czech public, housing loans (92\%) are the most acceptable type of loan, followed by loans for education and business $(73 \%$ and 71\%, respectively) [CVVM 2010].
} 
They spend money on such silly things.' (a man in the parental generation) Mortgages lack the association with risk.

On the other hand, the term investment can be used as the justification for spending a large sum of money. Unlike excessive and spontaneous shopping, which is generally portrayed as morally problematic, the notion of investment legitimises this kind of spending, because it inoculates spending with a productive meaning.

Using financial objects as metaphors, people refer, for example, to investments in people-in a wife or children. In this context, it should be noted that the way our respondents speak about these kinds of investments is heavily gendered and replicates the general family discourse. No wife spoke about her investment in her husband; however, several husbands referred to their investments in their wives. The way people refer to investments in other family members can be associated with the general image of who brings money into the family and who represents the family in general. Domestication through metaphors does not change the meaning of the original term, but it influences its semantic landscape. Financial objects are used in relational work and this usage might change the way people interpret them in relation to the financial discourse.

In terms of the investment, the crucial evaluative category is permanence and high quality: 'What's important for me is the permanence it provides me with.' (a man in the parental generation) Our respondents usually define an investment as something that costs a lot of money and holds its value for a long time. With respect to the future, they do not refer to a possible rise in value (as economists do) but speak much more about the investment maintaining its value over time. This difference corresponds with the general boundaries between the profit-making rational economy and the risk-avoiding moral family economy, and it resonates very strongly with Weber's distinction [1978] between wantsdriven households and profit-driven enterprises.

\section{Affectivation}

The boundaries of financial autonomy also have a very strong emotional dimension. Whereas narrativisation situates financial objects in time, appropriation puts them in the context of the family moral economy, and affectivation connects them to an authentic experience and triggers the binary code of the family moral economy in everyday situations.

In the following quotation, a respondent spoke about feeling ashamed if she needed to borrow from her mother.

I would never borrow even 100 crowns from my mother, since I'm married. You just plan your budget. I'd rather limit my needs than borrow money. I'd feel ashamed ... I have a job and I'm married. (a woman in the parental generation) 
The family discourse re-produces the moral economy of the family in everyday conversations, delineates the contours of socialisation, and converts the moral economy into emotional scripts. Emotional scripts connect the binary codes of family life with everyday situations, and they embody this moral order and construct it as taken-for-granted.

People use emotional scripts when referring to banks or banking advisors. The way they decide on financial objects, how they deal with them, and how they speak about them derives from the emotional feeling financial objects elicit. Debt has heavy negative connotations, arouses negative feelings, and is associated with personal failure and shame. On the other hand, mortgages can be associated with positive feelings.

As we show, moral judgement and emotions cannot be seen as discrete influences, and must instead be viewed as intertwined and reinforced, both in narrative practice and in mechanism of appropriation. In family discourse, financial objects are not neutral; their meaning is rather driven by emotional scripts, which help family members navigate the world of everyday financing.

\section{Conclusion}

The financialisation literature stresses the impact of financial products on family life. The discourse of financial institutions and products such as loans and mortgages is a familialising project, in Nicolas Rose's [1987] words, colonising the domestic sphere and family life. We believe that this is not a one-way processproceeding from the top down. Instead, the language of financial products is entangled in the local culture of domesticity and family discourse and practices. Family members re-articulate this discourse in everyday conversations and inoculate expert terms with special meaning. We portray the moral economy of the family as the key discourse from which meanings are derived and through which economic life is seen. The moral economy can be defined as collectively validated beliefs about just distribution and exchanges, beliefs which are rooted in social norms. Domestic monies are based much more upon kinship, face-to-face relationships, and respect for autonomy and identity.

The family-specific moral economy profoundly differs from the rational financial economy in relation to the future. While the rational financial economy is based upon promises about the future, the moral economy of the family sees the future as a threat. The language of opportunities that can be found in the financial rational economy is challenged by the language of risk-aversion in the domestic world. The discourse of the moral economy of the family is based upon its main obligation: 'to save in order to be prepared if something were to happen'. The moral economy of the family is maintained in everyday conversation and family practice and it can be embodied in feelings of shame or pride.

The meaning of a mortgage is derived from housing as a collective repre- 
sentation of the moral economy of the family. Family discourse on mortgages shows that financial institutions do not colonise family life with their impact on rationalisation and calculation; on the contrary, the moral evaluation of family life, with its emphasis on autonomy and stability, is what makes financial products valuable and meaningful. The language of family discourse grasps financial objects, re-orders them, and puts them in the domestic zone. We identify three methods by which this translation occurs: (1) narrativisation, (2) appropriation, and (3) affectivation. We portray families as active entities resisting the dominant discourse of the family economy.

The moral economy of Czech families may contain echoes of the experience with communism and historical memories of the drastic currency reforms that were introduced in the 1950s and the retreat into the private space in the 1970s and 1980s, when 'atomized society spontaneously restricted itself in discrete egalitarian family networks' [Možný amd Katrňák 2005: 238]. Families' reluctance to engage in risk behaviour and their stress on autonomy may also be the result of their post-socialist experience, amidst collapsing banks and investment funds in the 1990s and the current discourse of economic crisis.

Family discourse, with its emphasis on autonomy, strict consumption, riskaversion, and morality, resembles contemporary economic austerity policies. Some scholars [e.g. Schmidt and Thatcher 2013] have asked for the reason for the resiliency of austerity concepts, and it seems the answer to this may lie outside the realm of the state and economic policy. However, the answer to this riddle may also lie outside the economic discourse-in the ordinary lives of people and the ordinary ways in which they think about the economy, what stories they tell when they speak about the economy, and what feelings they have.

KAREL ČADA is a researcher in the Department of Sociology at the Faculty of Social Science of Charles University. His research focuses on economic sociology, discourse and narrative analysis, inequalities, migration, and social and health policies.

KateřInA PtÁČKOvá is an independent researcher. Her research interests include political sociology, policy analysis and decision-making, civil society, the public sphere, and democracy.

\section{References}

Aaker, J. L. and A. Y. Lee. 2001. "I" Seek Pleasures and "We" Avoid Pains: The Role of Self-Regulatory Goals in Information Processing and Persuasion.' Journal of Consumer Research 28 (June): 33-49, https://doi.org/10.1086/321946.

Aalbers, M. 2008. 'The Financialization of Home and Mortgage Market Crisis.' Competition \& Change 12: 148-166. 
Alexander, J. 2004. 'Cultural Pragmatics: Social Performance between Ritual and Strategy.' Sociological Theory 22 (4): 527-573, https://doi.org/10.1111/j.0735-2751.2004.00233.x.

Alexander, J. 2006. The Civil Sphere. Oxford: Oxford University Press, https://doi.org/10.1093/acprof:oso/9780195162509.001.0001.

Appadurai, A. 2016. Banking on Words: The Failure of Language in the Age of Derivative Finance. Chicago, IL: The University Chicago Press.

Atkinson, W. 2014. 'A Sketch of "Family" as a Field: From Realized Category to Space of Struggle.' Acta Sociologica 57: 223-235, https://doi.org/10.1177/0001699313511470.

Bandelj, N. 2012. 'Relational Work and Economic Sociology.' Politics E Society 40 (2): 175-201, https://doi.org/10.1177/0032329212441597.

Beckert, J. 2016. Imagined Futures: Fictional Expectations and Capitalist Dynamic. Cambridge, MA: Harvard University Press, https://doi.org/10.4159/9780674545878.

Blum-Kulka, S. 1990. 'You Don't Touch Lettuce with Your Fingers: Parental Politeness in Family Discourse.' Journal of Pragmatics 14 (2): 259-288, https://doi.org/10.1016/0378-2166(90)90083-P.

Bohanek, J., K. Marin, R. Fivush and M. Duke. 2006. 'Family Narrative Interaction and Adolescent Sense of Self.' Family Processes 45: 39-54, https://doi.org/10.1111/j.1545-5300.2006.00079.x.

Bourdieu, P. 1996. 'On the Family as a Realized Category.' Theory, Culture E Society 13 (3): 19-26, https://doi.org/10.1177/026327696013003002.

Bratman, M. E. 1992. 'Shared Cooperative Activity.' Philosophical Review 101 (2): 327-341, https://doi.org/10.2307/2185537.

Brown, N. and M. Michael. 2003. 'A Sociology of Expectations: Retrospecting Prospects and Prospecting Retrospects.' Technology Analysis and Strategic Management 15 (1): 3-18, https://doi.org/10.1080/0953732032000046024.

Churchill, G. A. and G. P. Moschis. 1979. 'Television and Interpersonal Influences on Adolescent Consumer Learning.' Journal of Consumer Research 6 (June): 23-35, https://doi.org/10.1086/208745.

Commuri, S. and J. W. Gentry. 2005. 'Resource Allocation in Households with Women as Chief Wage Earners.' Journal of Consumer Research 32 (September): 185-195, https://doi.org/10.1086/432228.

Cotte, J. and S. L. Wood. 2004. 'Families and Innovative Consumer Behavior: A Triadic Analysis of Sibling and Parental Influence.' Journal of Consumer Research 31 (June): 78-86, https://doi.org/10.1086/383425.

CVVM. (Public Opinion Research Centre) 2009. Postoje veřejnosti k vyrovnání se s minulostí. (Public Views on Settling the Past) Retrieved 5 September 2017 (https://cvvm.soc.cas. cz/media/com_form2content/documents /c2/a646/f9/100962s_po91103.pdf).

CVVM. (Public Opinion Research Centre) 2010. Názory obyvatel na pưjčky a dluhy. (Public Opinions on Loans and Debts) Retrieved 5 September 2017 (https://cvvm.soc.cas.cz/ media/com_form2content/documents/c2/a519/f9/101017s_er100310b.pdf).

Czarniawska, B. 2004. Narratives in Social Science Research. London, Thousand Oaks, CA, and New Delhi: Sage Publications, https://doi.org/10.4135/9781849209502.

Daly, M. and G. Kelly. 2015. Families and Poverty: Everyday Life on a Low Income. Bristol: Policy Press.

Day Sclater, S. 2008. 'Family Discourses and Family Practices.' Pp. 125-154 in Understanding Family Meanings: A Reflective Text, edited by J. Ribbens McCarthy, M. Doolittle and S. Day Sclater. Bristol: The Policy Press and the Open University.

Dodd, N. 2014. The Social Life of Money. Princeton, NJ, and Oxford: Princeton University Press, https://doi.org/10.1515/9781400852048.

Engelen, E. 2008. 'The Case for Financialization.' Competition \& Change 12: 111-119. 
Fivush, R. 2008. 'Remembering and Reminiscing: How Individual Lives Are Constructed in Family Narratives.' Memory Studies 1 (1): 49-58, https://doi.org/10.1177/1750698007083888.

Gamble, A. 2013. 'Neo-liberalism and Fiscal Conservatism.' Pp. 53-76 in Resilient Liberalism in Europe's Political Economy, edited by V. A. Schmidt and M. Thatcher. Cambridge: Cambridge University Press, https://doi.org/10.1017/CBO9781139857086.004.

Gillies, V. 2003. 'Family and Intimate Relationships: A Review of the Sociological Research.' London: Families \& Social Capital ESRC Research Group, South Bank University.

Gordon, C. 2007. 'I Just Feel Horribly Embarrassed When She Does That: Constituting a Mother's Identity.' Pp. 71-101 in Family Talk: Discourse and Identity in Four American Families, edited by D. Tannen, S. Kendall and C. Gordon. New York: Oxford University Press.

Granovetter, M. 1985. 'Economic Action and Social Structure: The Problem of Embeddedness.' American Journal of Sociology 91 (3): 481-510, https://doi.org/10.1086/228311.

Gubrium, J. F. and J. A. Holstein. 1993. 'Family Discourse, Organizational Embeddedness, and Local Enactment.' Journal of Family Issues 14 (1): 66-81, https://doi.org/10.1177/0192513X93014001006.

Habermas, J. 1987. The Theory of Communicative Action, Vol. II: Lifeworld and System. Boston, MA: Beacon.

Hamilton, R. W. and G. W. Biehal. 2005. 'Achieving Your Goals or Protecting Their Future? The Effects of Self-View on Goals and Choices.' Journal of Consumer Research 32 (September): 277-283, https://doi.org/10.1086/432237.

Haney, L. and M. March. 2003. 'Married Fathers and Caring Daddies: Welfare Reform and the Discursive Politics of Paternity.' Social Problems 50 (4): 461-481, https://doi.org/10.1525/sp.2003.50.4.461.

Hochschild, A. R. 2003. The Commercialisation of Intimate Life: Notes from Home and Work. Berkeley, CA: University of California Press.

Holmes, D. 2014. Economy of Words: Communicative Imperatives in Central Banks. Chicago, IL: University of Chicago Press.

Holstein, J. A. and J. F. Gubrium. 2008. 'Constructionist Impulses in Ethnographic Fieldwork.' Pp. 373-395 in Handbook of Constructionist Research, edited by J. A. Holstein and J. F. Gubrium. New York: The Guilford Press.

Klein, W., C. Izquierdo and T. N. Bradbury. 2013. 'Housework.' Pp. 94-110 in Fast Forward Family: Home, Work, and Relationships in Middle Class America, edited by E. Ochs and T. Kremer-Sadlik. Berkeley, CA: University of California Press.

Krippner, G. 2012. Capitalizing on Crisis: The Political Origins of the Rise of Finance. Cambridge, MA: Harvard University Press.

Lai, K. P. Y. 2016. Unpacking Financial Subjectivities: Intimacies, Governance and Socioeconomic Practices in Financialisation. Working paper, Department of Geography, National University of Singapore.

Lamont, M. and L. Thevenot. 2000. Rethinking Comparative Cultural Sociology: Repertoires of Evaluation in France and the United States. Cambridge: Cambridge University Press, https://doi.org/10.1017/CBO9780511628108.

Maesse, J. 2015. 'Economic Experts: A Discursive Political Economy of Economics.' Journal of Multicultural Discourses 10 (3): 279-305, https://doi.org/10.1080/17447143.2015.1050029.

Martin, R. 2002. Financialization of Daily Life. Philadelphia, PA: Temple University Press. 
McCloskey, D. 2016. Bourgeois Equality: How Ideas, Not Capital or Institutions, Enriched the World. Chicago, IL, and London: The University of Chicago Press.

Montgomerie, J. 2006. 'The Financialization of the American Credit Card Industry.' Competition \& Change 10: 301-319, https:// doi.org/10.1179/102452906X114393.

Moore, E. S. and W. L. Wilkie. 2005. 'We Are Who We Were: Intergenerational Influences in Consumer Behavior.' Pp. 208-293 in Inside Consumption: Frontiers of Research on Consumer Motives, Goals and Desires, edited by S. Ratneshwar and D. G. Mick. New York: Routledge.

Morduch, J. 2017. 'Economics and the Social Meaning of Money.' Pp. 25-38 in Money Talks: Explaining How Money Really Works, edited by N. Bandelj, F. F. Wherry and V. Zelizer. Princeton, NJ, and Oxford: Princeton University Press, https://doi.org/10.1515/9781400885268-004.

Morgan, D. H. 1996. Family Connections. Cambridge: Polity Press.

Morgan, D. H. 2011. Rethinking Family Practices. Basingstoke: Palgrave Macmillan, https://doi.org/10.1057/9780230304680.

Moschis, G. P. and G. A. Churchill. 1978. 'Consumer Socialization: A Theoretical and Empirical Analysis.' Journal of Marketing Research 15 (November): 599-609, https://doi.org/10.2307/3150629.

Možný, I. and P. Katrňák. 2005. 'The Czech Family.' Pp. 235-261 in Handbook of World Families, edited by B. N. Adams and J. Trost. Thousand Oaks, CA, London and New Delhi: Sage Publications, https://doi.org/10.4135/9781412975957.n11.

Ochs, E. and T. Kremer-Sadlik. 2015. 'How Postindustrial Families Talk.' Annual Review of Anthropology 44: 87-103, https://doi.org/10.1146/annurev-anthro-102214-014027.

Ochs, E. and C. Taylor. 1995. 'The "Father Knows Best" Dynamic in Family Dinner Narratives.' Pp. 97-121 in Gender Articulated: Language and the Socially Constructed Self, edited by K. Hall and M. Bucholtz. New York and London: Routledge.

Orleán, A. 2014. The Empire of Value: A New Foundation for Economics. Cambridge, MA, and London: MIT Press, https://doi.org/10.7551/mitpress/9780262026970.001.0001.

Pellandini-Simányi, L., F. Hammer and Z. Vargha. 2015. 'The Financialization of Everyday life or the Domestication of Finance?' Cultural Studies 29 (5-6): 733-759, https://doi.org/10.1080/09502386.2015.1017142.

Phillips, J. 2009. 'Attention, Shoppers-Family Being Constructed on Aisle Six: Grocery Shopping and Accomplishment of Family.' Pp. 92-108 in Lived Experience of Public Consumption: Encounters with Value on Five Continents, edited by D. T. Cook. Basingstoke: Palgrave Macmillan.

Pontecorvo, C. and A. Fasulo. 1999. 'Planning a Typical Italian Meal: A Family Reflection on Culture.' Culture and Psychology 5 (3): 313-335, https://doi.org/10.1177/1354067X9953004.

Pratt, M. W. and B. H. Fiese. 2004. Family Stories and the Life Course: Across Time and Generations. Mahwah, NJ: Erlbaum.

Rona-Tas, A. and A. Guseva. 2014. Plastic Money: Constructing Markets for Credit Cards in Eight Postcommunist Countries. Stanford, CA: Stanford University Press.

Rose, N. 1987. 'Beyond the Public/Private Division: Law, Power and the Family.' Journal of Law and Society 14 (1): 61-76, https://doi.org/10.2307/1410297.

Sayer, A. 2000. 'Moral Economy and Political Economy.' Studies in Political Economy 61: 79-104, https://doi.org/10.1080/19187033.2000.11675254.

Sayer, A. 2015. Why We Can't Afford the Rich. Bristol: Policy Press.

Schmidt, V. and M. Thatcher. 2013. 'Theorizing Ideational Continuity: The Resilience of Neoliberal Ideas in Europe.' Pp. 1-50 in Resilient Liberalism in Europe's Political Economy, edited by V. Schmidt and M. Thatcher. Cambridge: University Cambridge Press, https://doi.org/10.1017/CBO9781139857086.002. 
Schultz, W. A. 1974. Economics of the Family: Marriage, Children, and Human Capital. Chicago, IL: University of Chicago Press.

Scott, J. 1976. The Moral Economy of the Peasant: Rebellion and Subsistence in Southeast Asia. New York: Yale University Press.

Sen, A. 1991. On Ethics and Economics. Malden, Oxford, and Carlton: Blackwell Publishing.

Silverstone, R., E. Hirsch and D. Morley. 1992. 'Information and Communication Technologies and the Moral Economy of the Household.' Pp. 9-17 in Consuming Technologies: Media and Information in Domestic Spaces, edited by R. Silverstone and E. Hirsch. London and New York: Routledge, https://doi.org/10.4324/9780203401491_chapter_1.

Singh, S. 1997. Marriage Money: The Social Shaping of Money in Marriage and Banking. Melbourne: Allen \& Unwin.

Thaler, R. H. 1999. 'Mental Accounting Matters.' Journal of Behavioral Decision Making 12 (3): 183-206, https:// doi.org/10.1002/(SICI)1099-0771(199909)12:3\%3C183::AIDBDM318\%3E3.0.CO;2-F.

Tian, K. and R. W. Belk. 2005. 'Extended Self and Possessions in the Workplace.' Journal of Consumer Research 32 (September): 297-310, https://doi.org/10.1086/432239.

Weber, M. 1978. Economy and Society: An Outline of Interpretative Sociology. Berkeley, Los Angeles, CA, and London: The University of California Press.

Wherry, F. F. 2017. 'How Relational Accounting Matters.' Pp. 57-71 in Money Talks: Explaining How Money Really Works, edited by N. Bandelj, F. F. Wherry and V. Zelizer. Princeton, NJ, and Oxford: Princeton University Press.

Zelizer, V. A. 1989. 'The Social Meaning of Money: "Special Monies".' American Journal of Sociology 95 (2): 342-377, https://doi.org/10.1086/229272.

Zelizer, V. A. 2004. The Social Meaning of Money: Pin Money, Paychecks, Poor Relief and Other Currencies. New York: Basic Books.

Zelizer, V. A. 2012. 'How I Became a Relational Economic Sociologist and What Does That Mean?' Politics \& Society 40 (2): 145-174, https://doi.org/10.1177/0032329212441591. 